\title{
The Effect Of Good Corporate Governance Mechanism On The Financial Perofrmance Of Registered Banking Companies On The Stock Exchange
}

Yolanda Permatasari Nababan

Department of Accounting, Univesity Of North Sumatra, Indonesia

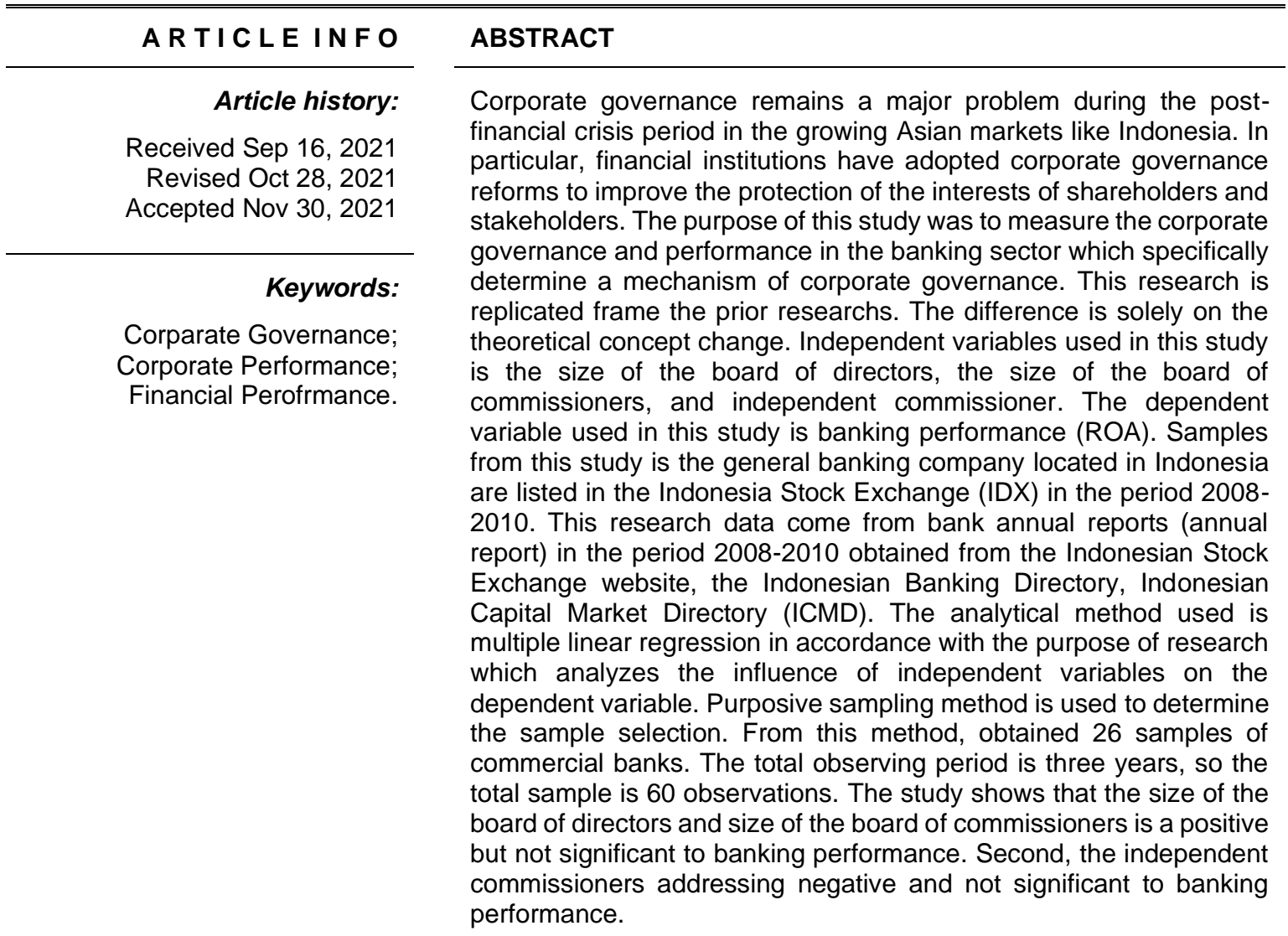

This is an open access article under the CC BY-NC license.

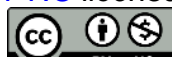

\section{Corresponding Author:}

Yolanda Permatasari Nababan, Department of Accounting, University Of North Sumatra, Indonesia, Jl. Dr. Mansur No. 9 Padang Bulan, Kec. Medan Baru, Kota Medan 20222. Email: yolandanababan@gmail.com

\section{INTRODUCTION}

One of the important goals of establishing a company is to increase the welfare of its owners or shareholders, or maximize shareholder wealth through increasing the value of the company (Brigham and Houston, 2001). The increase in the value of the company can be achieved if the company is able to operate by achieving the targeted profit. Through the profits obtained, the company will be 
able to provide dividends to shareholders, increase the company's growth and maintain its viability. The obstacles faced by the company in achieving the company's goals generally revolve around things that are fundamental, namely: (1) The need for the company's ability to manage its resources effectively and efficiently, which covers all areas of activity (human resources, accounting, management, marketing and production), (2) Consistency in the separation system between management and shareholders, so that practically the company is able to minimize conflicts of interest that may occur between management and shareholders and (3) The need for the company's ability to create trust in people with disabilities. external funds, that external funds are used appropriately and efficiently as possible and ensure that management acts in the best interests of the company. To overcome these obstacles, companies need to have a good corporate management system, which is able to provide effective protection to shareholders and creditors, so that they can assure themselves that they will get a fair and high value return on their investment.

The conditions faced by public companies in Indonesia are still weak in managing companies. This is shown by the still weak accounting standards and regulations, accountability to shareholders, disclosure and transparency standards as well as company management processes. This fact indirectly shows that public companies in Indonesia are still weak in carrying out good management in satisfying company stakeholders. In an effort to overcome these weaknesses, business people in Indonesia agreed on the implementation of Good Corporate Governance (GCG), which is a good corporate management system, this is in accordance with the signing of the Letter of Intent (LOI) agreement with the IMF in 1998, one of the contents of which is the inclusion of a schedule for improving the management of companies in Indonesia (Sulistyanto, 2003). It's hard to deny, over the last ten years, the term GCG has become increasingly popular. Not only popular, but the term is also placed in a respectable position. This is manifested in at least two beliefs. First, GCG is one of the keys to a company's success to grow and be profitable in the long term, while winning global business competition, especially for companies that have been able to develop and become open. Second, the world economic crisis in Asia and Latin America is believed to have arisen due to the failure to implement GCG. Since the financial crisis in various countries in 1997-1998 which began with the crisis in Thailand (1997), Japan, Korea, Indonesia, Malaysia, Hong Kong and Singapore which eventually turned into the Asian financial crisis were seen as a result of weak practices of Good Corporate Governance (GCG) in Asian countries. This is due to the relatively similar objective conditions in these countries, including the close relationship between the government and business actors, conglomeration and monopoly, protection, and market intervention, thus making these countries unprepared to enter the era of globalization and free markets. (Tjager et al., 2003).

The failure of several companies and the emergence of cases of financial malpractice as a result of the crisis are evidence of poor Corporate Governance (CG) practices. According to Pangestu and Hariyanto (in Suprayitno et al., 2004), the characteristics of weak corporate governance practices in Southeast Asia are (1) the concentration of ownership and power of insider shareholders (including the government and parties related to the power center), (2) weak governance of the financial sector, and (3) the ineffectiveness of internal rules and the absence of legal protection for minority shareholders to deal with majority shareholders and managers.

The implementation of good corporate governance is considered to be able to improve the performance and image of the banking industry, which had a bad reputation, protect the interests of stakeholders and improve compliance with applicable laws and regulations and general ethics in the banking industry in order to create a sound banking system. In addition, the implementation of good corporate governance in banking is expected to affect banking performance, because the implementation of corporate governance can improve financial performance, reduce risks due to management actions that tend to benefit themselves.

\section{RESEARCH METHOD}

This study uses a causal associative design. According to Erlina (2008:34), "associative research is connecting two or more variables". According to Sugiyono (2007:30) causal design is research that aims to analyze the causal relationship between the independent variable (the variable that affects) and the dependent variable (the variable that is influenced). 
So causal associative research is research that explains the causal relationship of two or more variables to analyze how one variable affects other variables. This study examines the effect of good corporate governance mechanisms on the company's financial performance.

\subsection{Multicollinearity Test}

The multicollinearity test aims to test whether there is a correlation between the independent variables in the regression model. A good regression model should not have a correlation between independent variables.

To detect the presence or absence of multicollinearity, it can be seen from the VIF (Variance Inflation Factor) value and the tolerance value. In this test, the multicollinearity-free regression is the one that has a VIF value of less than 10 and a tolerance value of not less than 0.1 . VIF $=1 /$ Tolerance, if $\mathrm{VIF}-10$, then tolerance $=1 / 10=0.1$.

\section{a. Autocorrelation Test}

The autocorrelation test aims to test whether in a linear regression model there is a correlation between the confounding error in period $t$ and the error in period $t-1$ or before. Autocorrelation arises because successive observations throughout the year are related to one another. One way to find out whether there is autocorrelation is the Durbin Watson test (DW test). The DW test is calculated based on the sum of the differences in the squares of the estimated value of the successive disturbance factors. The Durbin Watson test is only used for first order autocorrelation and requires an intercept (constant) in the regression model and there are no variables among the independent variables.

\section{b. Heteroscedasticity Test}

The heteroscedasticity test aims to test whether in a regression model there is an inequality of variance from the residuals from one observation to another. If the residual variance of one

Observations to other observations remain then it is called homoscedasticity, and vice versa if the variance is different then it is called heteroscedasticity. To find out whether there is heteroscedasticity in the regression model, it can be seen on the Scatterplot graph. If the points in the graph spread do not form a certain pattern (wave, widen, then narrow), and are spread both above and below the number 0 on the $\mathrm{Y}$ axis, then there is no heteroscedasticity. A good regression model is that there is no heteroscedasticity (Erlina and Mulyani, 2007:108)

\section{c. Hypothesis test}

This hypothesis testing aims to test whether the independent variables, namely the size of the board of directors, the size of the board of commissioners, and the independent commissioner partially affect the dependent variable, namely ROA.

\section{d. Determination Test $\left(\mathbf{R}^{2}\right)$}

For regression with more than two independent variables, adjusted $\mathrm{R}^{2}$ is used as the coefficient of determination. The adjusted $\mathrm{R}^{2}$ test is used to measure the proportion or percentage of the contribution of the independent variable studied to the variation of the ups and downs of the dependent variable.

\section{RESULTS AND DISCUSSIONS}

\subsection{Descriptive Statistical Analysis}

Descriptive statistical analysis provides information about the minimum value, maximum value, average value (mean), and standard deviation of the data used in the study.

Table 1. Descriptive Statistics Descriptive Statistics

\begin{tabular}{lccccc}
\hline & $\mathrm{N}$ & Minimum & Maximum & mean & Std. Deviation \\
\hline BOARD OF DIRECTORS & 78 & 3,000 & 11,000 & 6.93590 & 2.615338 \\
BOARD OF COMMISSIONERS & 78 & 1,000 & 9,000 & 5.01282 & 1.826881 \\
PROPORTION_DEWAN_FE & 78 & .000 & 1,000 & .58460 & .172023 \\
COMMISSIONER INDEPE NDEN & & & &
\end{tabular}




\begin{tabular}{lccccc}
\hline & $\mathrm{N}$ & Minimum & Maximum & mean & Std. Deviation \\
\hline ROA & 78 & .070 & 4.640 & 1.77679 & 1.133428 \\
Valid N (listwise) & 78 & & & & \\
\hline
\end{tabular}

Based on the data from table 11 it can be explained that:

a. The variable of the Board of Directors has a range from 3 to 11 with an average of 6.9359. The size of the Board of Directors is the number of the board of directors in a bank company. The higher the number of the Board of Directors, it indicates the size of the company is getting bigger and more complex.

b. The variable of the Board of Commissioners has a range from 1 to 9 with an average of 5.01282 . The size of the Board of Commissioners shows the number of the board of commissioners in a bank company. Banks that have a large size will usually have greater agency problems (because it is difficult to monitor) so that more supervisory functions are needed by increasing the number of commissioners.

c. The Independent Board of Commissioners variable has a range between 0 to 1 with an average of 0.5846 . The proportion of Independent Commissioners shows the percentage of independent commissioners to the number of commissioners in bank companies.

d. The ROA variable (performance measure) has a range between 0.070 to 4.64 with an average of 1.7769. ROA is the ratio of profit before tax (net income) divided by total assets. The higher the ROA value indicates efficient management in using its assets to generate income.

\subsection{Classical Assumption Test}

\section{a. Normality Test}

The normality test aims to test whether in the regression model, the residual variable has a normal data distribution or not, by making the following hypothesis:

Ho: the residual variable is not normally distributed, Ha: the residual variable is normally distributed. There are two ways to detect whether the data distribution is normal or not, namely by graph analysis and statistical tests.

\section{b. Graphic Analysis}

Graph analysis can be seen using histogram graphs and normal probability plot graphs. In a histogram graph, the normal distribution of data is indicated by a curve or histogram image that is neither skewed to the left nor skewed to the right. Whereas in the normal probability plot graph, the normal data distribution will form a straight diagonal line, and plotting the residual data will be compared with the diagonal line. Normality can be detected by looking at the distribution of plotting residual data on the diagonal axis. The data distribution pattern is said to be normal if the plotting of residual data spreads around the diagonal line and follows the diagonal direction.

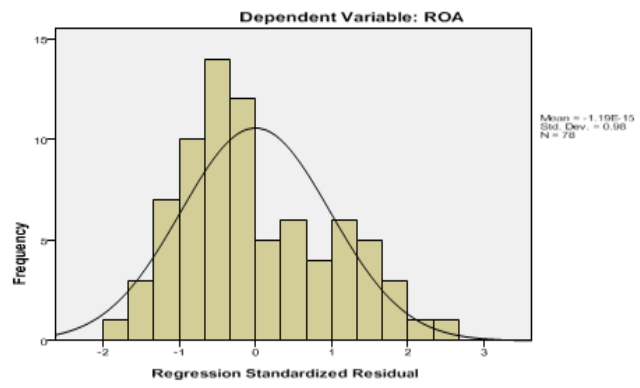

Figure 1. Histogram Graph 


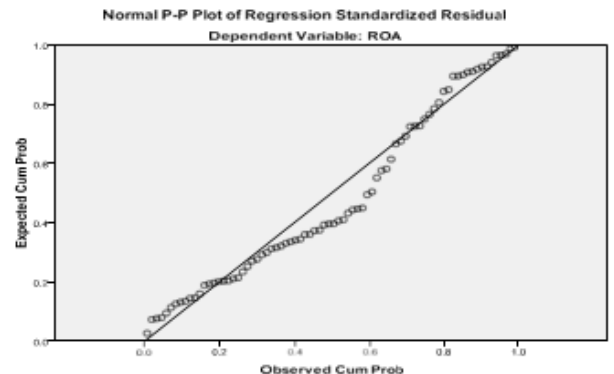

Figure 2. Normal Probability Plot

In Figure 1, it can be seen that the histogram graph is not skewed to the left or right, this indicates that the data distribution is normal. This is supported by Figure 2, where the plotting of residual data spreads around the diagonal line and follows the diagonal direction. Both figures show that the regression model meets the assumption of normality.

However, the normality test using graphical analysis can be misleading because sometimes the data looks normal, even though the data is not necessarily normally distributed. And sometimes it looks abnormal, even though the data is normally distributed. Therefore, to ascertain whether the data is normally distributed or not, a statistical analysis test is carried out.

\section{c. Statistical Analysis}

Normality test with statistical analysis method using Kolmogorov - Smirnov test (1 sample KS). This test is carried out to determine whether the plotting of residual data that spreads around the diagonal line is normally distributed or not. The distribution of data is said to be normal if the asymptonic significance value is greater than $0.05(\square>0.05)$. And if on the other hand the asymptonic significance value is less than $0.05(\square<0.05)$, then the data distribution is not normal. The results of the Kolmogorov-Smirnov test can be seen in table 3 .

Table 3. Normality Test Results

One-Sample Kolmogorov-Smirnov Test

\begin{tabular}{ccc}
\hline & & Unstandardize d \\
& Residual \\
\hline $\mathrm{N}$ & mean & 78 \\
Normal Parameters, b & Std. Deviation & .000000 \\
Most Extreme Differences & Absolute & 1.08167576 \\
& Positive & .140 \\
& Kolmogorov-Smirnov Z & .140 \\
& negative & -.079 \\
asymp. Sig. (2-tailed) & 1,238 \\
& & .093 \\
\hline
\end{tabular}

Test distribution is Normal.

In the statistical analysis test results shown in table 4.2 , it can be seen that the asymptonic significance value of 0.093 is greater than 0.05 , it is stated that the data in this study are normally distributed ( $\mathrm{Ha}$ is accepted).

\section{d. Multicollinearity Test}

Multicollinearity test aims to test whether the regression model found a correlation between the independent variables (independent). A good regression model should not have a correlation between the independent variables. Multicollinearity can be seen from the value of the variance inflation factor (VIF) and tolerance. To detect the presence or absence of multicollinearity, it can be done by looking at the VIF value and variable tolerance with the following hypothesis:

Ho: there is multicollinearity; VIF $>10$, Tolerance $<0,1$, Ha: there is no multicollinearity; VIF $<10$, Tolerance $>0.1$. 
Table 4. Multicollinearity Test Results

\begin{tabular}{|c|c|c|c|c|c|c|c|}
\hline \multicolumn{8}{|c|}{ Coefficientsa } \\
\hline \multirow[t]{2}{*}{ Model } & \multicolumn{2}{|c|}{$\begin{array}{l}\text { Unstandardized } \\
\text { Coefficients }\end{array}$} & \multirow{2}{*}{$\begin{array}{l}\text { Standardized } \\
\text { Coefficients } \\
\text { Beta }\end{array}$} & \multirow[t]{2}{*}{$t$} & \multirow[t]{2}{*}{ Sig. } & \multicolumn{2}{|c|}{ Collinearity Statistics } \\
\hline & B & Std. Error & & & & Tolerance & VIF \\
\hline 1(Constant) & 1,001 & .685 & & 1,462 & .148 & & \\
\hline BOARD OF DIRECTORS & .118 & .072 & 273 & 1,642 & .105 & 446 & 2,241 \\
\hline $\begin{array}{c}\text { BOARD OF } \\
\text { COMMISSIONERS }\end{array}$ & .013 & .102 & .021 & .129 & .897 & .454 & 2.201 \\
\hline $\begin{array}{l}\text { PROPORTION_BOARD_E } \\
\text { COMMISSIONER_INDEPE } \\
\text { NDEN }\end{array}$ & -189 & .769 & -.029 & -.246 & .807 & .904 & 1.106 \\
\hline
\end{tabular}

Based on table 4, it can be seen that there is no variable with a VIF value greater than 10 and a tolerance value less than 0.1 . Thus, it can be stated that the regression model in this study is free from multicollinearity ( $\mathrm{Ha}$ is accepted).

\section{e. Autocorrelation Test}

The autocorrelation test aims to test whether in the linear regression model there is a correlation between the confounding error in period $t$ and the confounding error in period $t-1$ or the previous period. The autocorrelation test was carried out using the Durbin-Watson (DW) test. The criteria for assessing the occurrence of autocorrelation are:

1) DW numbers below -2, it means that there is a positive autocorrelation,

2) DW numbers between -2 to +2 , meaning there is no autocorrelation

3) DW numbers above +2 , it means that there is a negative autocorrelation.

Table 5. Durbin Watson Test Results Model Summaryb

\begin{tabular}{cccccc}
\hline Model & $\mathrm{R}$ & $\mathrm{R}$ Square & Adjusted R Square & $\begin{array}{c}\text { Std. Error of the } \\
\text { Estimate }\end{array}$ & Durbin-Watson \\
\hline 1 & $.299 \mathrm{a}$ & .089 & .052 & 1.103384 & 1,679 \\
\hline
\end{tabular}

\section{f. Heteroscedasticity Test}

The heteroscedasticity test aims to test whether in the regression model there is an inequality of variance from one observation to another observation. A good regression model is that there is no heteroscedasticity.

Heteroscedasticity test can be done by two methods, namely graph test and glejser test. The graph test is done by looking at the scatterplot graph, if the points spread randomly and do not form a certain clear pattern and are spread above and below zero on the $Y$ axis. This means that it does not indicate that there is no heteroscedasticity in the regression model. Meanwhile, the Glejser test is carried out by regressing all independent variables with the absolute residual (absut) value as the dependent variable. The regression model does not occur heteroscedasticity if the significant value is $>0.05$ but if the significant value is $<0.05$ then heteroscedasticity occurs in the regression model.

Table 5. Glejser Test Results Coefficientsa

\begin{tabular}{|c|c|c|c|c|c|}
\hline \multirow[t]{2}{*}{ Model } & \multicolumn{2}{|c|}{$\begin{array}{l}\text { Unstandardized } \\
\text { Coefficients }\end{array}$} & \multirow{2}{*}{$\begin{array}{l}\text { Standardized } \\
\text { Coefficients } \\
\text { Beta }\end{array}$} & \multirow[t]{2}{*}{$\mathrm{t}$} & \multirow[t]{2}{*}{ Sig. } \\
\hline & B & Std. Error & & & \\
\hline 1 (Constant) & 1,001 & .685 & & 1,462 & .148 \\
\hline BOARD OF DIRECTORS & .118 & .072 & 273 & 1,642 & .105 \\
\hline $\begin{array}{c}\text { BOARD OF } \\
\text { COMMISSIONS RIS }\end{array}$ & .013 & 102 & .021 & .129 & .897 \\
\hline $\begin{array}{c}\text { PROPORTION_DEWA } \\
\text { N_COMISSIONER_IN } \\
\text { DEPENDENT }\end{array}$ & -189 & .769 & -.029 & -.246 & .807 \\
\hline
\end{tabular}


In Figure 5, the scatterplot graph shows the points that spread randomly and do not form a certain clear pattern and are spread both above and below zero on the $Y$ axis. And in table 4.5 above shows that the significant value of all independent variables is greater than 0,05 . This means that there is no heteroscedasticity in the regression model so that the regression model is feasible to use to see the effect of the independent variable on the dependent variable.

\subsection{Hypothesis Test}

\section{a. Determination Test (R2)}

The coefficient of determination is used to measure how far the model's ability to explain the variation of the independent variables. The value of the coefficient of determination is 0 The greater the value of the coefficient of determination, the better. In this case the researcher uses the Adjusted $\mathrm{R} 2$ value, because the researcher examines more than two variables. Adjusted $\mathrm{R} 2$ can increase or decrease if one independent variable is added to the model. Similar to R2, Adjusted R2 is used to measure how far the model's ability to explain variations in independent variables is. The results of the measurement of the coefficient of determination can be seen in table 4.6 as follows:

Table 6. Determination Test Results Model Summaryb

\begin{tabular}{|c|c|c|c|c|}
\hline Model & $\mathrm{R}$ & $\mathrm{R}$ Square & $\begin{array}{c}\text { Adjusted } \mathrm{R} \\
\text { Square }\end{array}$ & $\begin{array}{c}\text { Std. Error of the } \\
\text { Estimate }\end{array}$ \\
\hline 1 & $.299 \mathrm{a}$ & .089 & .052 & 1.103384 \\
\hline
\end{tabular}

From the results of hypothesis testing using SPSS 18 obtained the Adjusted R2 value of 0.089 . Thus the magnitude of the influence given by the variables of the board of directors, the board of commissioners, and the proportion of the independent board of commissioners on ROA is $8.9 \%$, while the remaining $91.1 \%$ is explained by other factors not examined in this study.

\section{b. Simultaneous Significance Test (F-Test)}

The $\mathrm{F}$ test aims to determine the effect of the independent variables together on the dependent variable. The $\mathrm{F}$ test can be searched by looking at the Fcount from the Anova table.

Hypothesis: Ho: the independent variable has no simultaneous effect on the dependent variable, $\mathrm{Ha}$ : the independent variable has a simultaneous effect on the dependent variable.

\section{c. Partial Significance Test (T - Test)}

$T$ test aims to determine how much influence the independent variable has on the dependent variable. This test is carried out using the following hypotheses and conditions:

\begin{tabular}{cccccc}
\multicolumn{7}{c}{$\begin{array}{c}\text { Table 7. t test results } \\
\text { Coefficientsa }\end{array}$} \\
\hline Model & Unstandardized Coefficients & $\begin{array}{c}\text { Standardized } \\
\text { Coefficients } \\
\text { Beta }\end{array}$ & $\mathrm{t}$ & & \\
& $\mathrm{B}$ & Std. Error & Sig. & \\
\hline (Constant) & 1,001 & .685 & & 1,462 & .148 \\
BOARD OF DIRECTORS & .118 & .072 & .273 & 1,642 & .105 \\
BOARD OF & .013 & .102 & .021 & .129 & .897 \\
COMMISSIONERS & -189 & .769 & -.029 & -.246 & .807 \\
BOARD OF \\
COMMISSIONERS \\
INDEPENDENT
\end{tabular}

\section{CONCLUSION}

The multiple regression model used in this study is quite feasible, because it passes four tests against the classical assumptions, namely the multicollinearity test, autocorrelation test, heteroscedasticity test and normality test.

The results of the calculation obtained the value of Fcount of 2.417 with a significance level of Fcount is 0.073 . This means that the significance value of Fcount is greater than 0.05 which indicates 
that the variables of the board of directors, the board of commissioners, and the independent board of commissioners simultaneously or together have no significant effect on ROA.

The Board of Directors variable partially has a positive but not significant effect on ROA seen from the significance value of 0.105 , which means it is greater than 0.05 . Based on the regression equation, it can be seen that the coefficient for the board of directors variable is positive, so it can be interpreted that the effect given by the board of directors variable on ROA is positive. This condition implies that the higher the size of the company's board of directors, the higher the ROA of the company.

The board of commissioners variable partially has a positive but not significant effect on ROA seen from the significance value of 0.897 which means it is greater than 0.05 . Based on the regression equation, it can be seen that the coefficient for the ROE variable is positive, so it can be interpreted that the influence given by the board of commissioners variable on ROA is positive. This condition implies that the larger the size of the company's board of commissioners, the higher the ROA of the company.

The independent board of commissioners variable partially has a negative and insignificant effect on ROA seen from the significance value of 0.807 , which means it is less than 0.05 . Based on the regression equation, it can be seen that the coefficient for the independent board of commissioners variable is negative, so it can be interpreted that the influence given by the independent board of commissioners variable on ROA is negative. This condition implies that the greater the proportion of the company's independent board of commissioners, the lower the ROA of the company.

\section{REFERENCES}

Arifin, Zaenal. 2005. Hubungan Antara Corporate Governance dan Variabel Pengurang Masalah Agensi, Jurnal Siasat Bisnis, Vol.1, No.10, Juni 2005, Hal. 39-55.

Bank Indonesia, 1998. Surat Keputusan Direksi Bank No.30/277/KEP/DIR Tanggal 19 Maret 1998 tentang Cara Penilaian Tingkat Kesehatan Bank.

Bank Indonesia. 2006. Peraturan BI No 8/4/PBI/2006 tentang Penerapan GCG Bagi Bank Umum yang Telah Diubah dengan Peraturan Bank Indonesia No 8/14/PBI/2006.

Bank for International Settlements, Basle Comitte on Banking Supervision, (1998) Framework for Internal Control Systems in Banking Organization.

Bringham, E.F., dan Houston J.F., 2001. Manajemen Keuangan . Edisi Delapan (Terjemahan), Salemba Empat, Jakarta.

Erlina dan Sri Mulyani, 2007. Metodologi Penelitian Bisnis, USU Press, Medan. Erlina, 2011. Metodologi Penelitian, USU Press, Medan.

Faisal, 2005, Analisis Agency Cost, Struktur Kepemilikan dan Mekanisme Corporate Governance, Jurnal Riset Akuntansi Indonesia, Vol.8, No.2, Hal 175-190.

Fakultas Ekonomi USU, Departemen Akuntansi, 2011. Buku Petunjuk Teknis Penulisan Proposal Penelitian dan Penulisan Skripsi, USU Press, Medan.

Firmansyah, 2006. Analisis Hubungan Struktur Kepemilikan dengan Kinerja Keuangan Perusahaan Perbankan Persero dan Perusahaan Perbankan Nasional Go Public. Skripsi Fakultas Ekonomi Universitas Islam Indonesia Yogyakarta. (Dipublikasikan).

Gozali, Imam., 2002. Analisis Multivariate dengan Program SPSS. Badan Penerbit Universitas Diponegoro, Semarang.

Gunarsih, Tri., 2003. Struktur Kepemilikan Sebagai Salah Satu Mekanisme Corporate Governance. Kompak Nomor 8.

Jensen, M.C. and W.H. Meckling, 1976. Theory of The Firm: Managerial Behavior, Agency Cost and Ownership Stucture, Journal of Financial Economics 3 (4): 305-360.

Jerab, Daoud., 2011. The Effect Of Internal Corporate Governance Mechanism on Corporate Performance, Journal of Economic.

Kesuma, Sambas Ade., 2005. Pengaruh Penerapan Corporate Governance terhadap Kinerja Perusahaan Manufaktur yang Listing di BEJ. Medan: Tesis. Sekolah Pasca Sarjana, Universitas Sumatera Utara.

Lastanti, Hexana Sri., 2004. Hubungan Struktur Corporate Governance Kinerja Perusahaan dan Reaksi Pasar, Konferensi Nasional Akuntansi: Peran Akuntan dalam Membangun Good Corporate Governance.

Maksum, Azhar., 2005. Tijauan atas Good Corporate Governance di Indonesia. Pidato Pengukuhan Jabatan Guru Besar Tetap dalam Bidang Ilmu Akuntansi Manajemen pada Fakultas Ekonomi. Medan: Universitas Sumatera Utara. 
Oktapiyani, Desi., 2009. Pengaruh Penerapan Corporate Governance terhadap Likuiditas Perbankan Nasional. Skripsi Fakultas Ekonomi Universitas Diponegoro, Semarang.

Paradita, Dita, 2009. Pengaruh Good Corporate Governance Terhadap Kinerja Keuangan Pada Perusahaan Yang Termasuk Kelompok Sepuluh Besar Menurut Corporate Governance Perception Index (CGPI) . Skripsi Fakultas Ekonomi USU (Dipublikasikan).

Praptiningsih, Maria. 2009. Corporate Governance and Performance of Banking Firms: Evidence From Indonesia, Thailand, Filipina, and Malaysia. Jurnal Manajemen dan Kewirausahaan, Vol.11, No.1, pp.94108.

Priambodo, R. dan E. Supriyatno. 2007. Penerapan Good Corporate Governance Sebagai Landasan Kinerja Perbankan. Usahawan No.5 Thn XXXVI Hal. 22-30, Jakarta.

Sari, Irmala, 2009. Pengaruh Mekanisme Good Corporate Governance terhadap kinerja Perbankan Nasional, Skripsi Fakultas Ekonomi Universitas Diponegoro, Semarang.

Sugiyono, 2006. Metode Penelitian Bisnis. Edisi 9, CV Alfabeta, Bandung.

Tjager, I.N., Alijoyo, F.A., Djemat, H.R., dan Soembodo, B., 2003. Corporate Governance. Prenhallindo, Jakarta. Tunggal, Imam Sjahputra dan Amin Widjaja Tunggal, 2002. Membangun Good Corporate Governance. Harvarindo, Jakarta.

Wardhani, Ratna. 2006. Mekanisme Corporate Governance dalam Perusahaan yang Mengalami Masalah Keuangan (Financial Distress Firms), Simposium Nasional Akuntansi IX, Padang, 23-26 Agustus 2006.

Wallace, P.\& J. Zinkin. 2005. Corporate Governance Mastering Business in Asia, Singapura: John Wiley \& Sons. 